\title{
EFFECTS OF ACTH ON THE UTERINE WEIGHT RESPONSE TO HCG IN MICE
}

\author{
B. VARGA, AGNES HRASCHEK AND G. FOLLY \\ Institute of Experimental Medicine, Hungarian Academy of Sciences, \\ Budapest 9, P.O.B. 67, Hungary \\ (Received 8th March 1974)
}

\begin{abstract}
Summary. The effects of ACTH and dexamethasone on the uterine weight of immature mice treated with HCG or oestradiol-17 $\beta$ were studied. The animals were treated daily for 3 days and wet and dry uterine weights were measured on the 4th day.

Low doses of ACTH $(1.25 \mu \mathrm{g} /$ day $)$ raised the sensitivity of the uterine weight response to threshold doses of HCG $(0.05$ to $0 \cdot 1 \mathrm{i}$.u. $)$. By increasing the doses of ACTH or HCG, the stimulation gradually turned into inhibition. By itself, ACTH was ineffective and it had no influence on the increase in uterine weight induced by oestradiol-17 $\beta$. Dexamethasone failed to stimulate the effect of HCG.
\end{abstract}

\section{INTRODUCTION}

Adrenocorticotrophic hormone is capable of influencing female gonadal function by increasing corticosteroid secretion by the adrenal gland (Hagino, Watanabe \& Goldzieher, 1969; Liptrap, 1970; Hagino \& Yamaoka, 1971; Smith, Johnson, Weick, Levine \& Davidson, 1971) or sex-steroid secretion (Resko, 1969; Feder \& Ruf, 1969; Feder, Brown-Grant \& Corker, 1971; Nequin \& Schwartz, 1971). It also significantly raises the ovarian blood flow in intact and adrenalectomized dogs and intact cats (Stark, Varga \& Ács, 1967; Stark \& Varga, 1968), golden hamsters (Varga, Stark, Csáki \& Marton, 1969) and guinea-pigs (Varga, 1972).

In intact and adrenalectomized dogs pretreated with HGG, low doses of ACTH were found to augment the rate of oestrogen secretion by the ovary as judged by the levels in blood samples from the ovarian vein (Varga, Horvath \& Stark, 1974). It has been shown that ACTH does not increase ovarian blood flow in the rat (Varga et al., 1969) and the mouse (Varga \& Bukulya, 1974). In order to establish whether ACTH is able to influence ovarian secretion of oestrogen without stimulation of ovarian blood flow, experiments were carried out on mice treated with HCG and the weight response of the uterus was measured.

\section{MATERIALS AND METHODS}

Immature mice of the CFLP strain, weighing 10 to $12 \mathrm{~g}$, were used. They were 
Table 1. Dose-response curves for the uterine weight of mice treated with HCG and gelatine or HCG and different doses of ACTH

\begin{tabular}{|c|c|c|c|}
\hline & \multirow[t]{2}{*}{ Treatment } & \multicolumn{2}{|c|}{ Wt of uterus (mg) } \\
\hline & & Wet & Dry \\
\hline Experiment A & $\begin{array}{c}\text { HGG }+1.5 \% \text { gelatine } \\
0.05 \text { i.u. }+0.1 \mathrm{ml} \\
0.10 \text { i.u. }+0.1 \mathrm{ml} \\
0.20 \text { i.u. }+0.1 \mathrm{ml} \\
0.40 \text { i.u. }+0.1 \mathrm{ml} \\
\text { HCG }+ \text { ACTH } \\
0.05 \text { i.u. }+1.25 \mu \mathrm{g} \\
0.10 \text { i.u. }+1.25 \mu \mathrm{g} \\
0.20 \text { i.u. }+1.25 \mu \mathrm{g} \\
0.40 \text { i.u. }+1.25 \mu \mathrm{g}\end{array}$ & $\begin{array}{c}28 \cdot 42 \pm 0 \cdot 90 \\
45 \cdot 41 \pm 3 \cdot 33 \\
41 \cdot 62 \pm 2 \cdot 50 \\
125 \cdot 57 \pm 11 \cdot 05 \\
\\
51 \cdot 86 \pm 4 \cdot 41 * * * \\
55 \cdot 32 \pm 4 \cdot 70 \\
50 \cdot 35 \pm 5 \cdot 79 \\
121 \cdot 82 \pm 8 \cdot 45\end{array}$ & $\begin{array}{c}5 \cdot 58 \pm 0.29 \\
7.38 \pm 0.55 \\
7 \cdot 45 \pm 0.28 \\
14.55 \pm 0.78 \\
\\
8 \cdot 35 \pm 0.67 * * * \\
8 \cdot 42 \pm 0.92 \\
8 \cdot 25 \pm 1.18 \\
13.76 \pm 2 \cdot 70\end{array}$ \\
\hline Experiment B & $\begin{array}{c}\text { HCG + 1.5\% gelatine } \\
0.1 \text { i.u. }+0.1 \mathrm{ml} \\
0.2 \text { i.u. }+0.1 \mathrm{ml} \\
0.4 \text { i.u. }+0.1 \mathrm{ml} \\
\text { HCG }+ \text { ACTH } \\
0.1 \text { i.u. }+1.25 \mu \mathrm{g} \\
0.2 \text { i.u. }+2.5 \mu \mathrm{g} \\
0.4 \text { i.u. }+5.0 \mu \mathrm{g}\end{array}$ & $\begin{array}{l}21 \cdot 00 \pm 1 \cdot 03 \\
40 \cdot 10 \pm 3.38 \\
67 \cdot 67 \pm 6 \cdot 34 \\
45 \cdot 14 \pm 4 \cdot 48 * * \\
38 \cdot 67 \pm 3 \cdot 18 \\
70 \cdot 24 \pm 5 \cdot 66\end{array}$ & $\begin{array}{c}5.25 \pm 0.21 \\
8.18 \pm 0.86 \\
11.68 \pm 0.39 \\
8.89 \pm 0.45 * * \\
8.09 \pm 0.37 \\
11.98 \pm 0.57\end{array}$ \\
\hline Experiment $\mathbf{C}$ & $\begin{array}{c}\text { HGG }+1.5 \% \text { gelatine } \\
0.2 \text { i.u. }+0.1 \mathrm{ml} \\
0.4 \text { i.u. }+0.1 \mathrm{ml} \\
0.8 \text { i.u. }+0.1 \mathrm{ml} \\
\text { HCG }+ \text { ACTH } \\
0.2 \text { i.u. }+1.25 \mu \mathrm{g} \\
0.4 \text { i.u. }+2.5 \mu \mathrm{g} \\
0.8 \text { i.u. }+5.0 \mu \mathrm{g}\end{array}$ & $\begin{array}{c}86 \cdot 29 \pm 6 \cdot 02 \\
118 \cdot 30 \pm 7 \cdot 83 \\
144 \cdot 05 \pm 11 \cdot 66 \\
\\
105 \cdot 75 \pm 6 \cdot 28^{*} \\
101 \cdot 50 \pm 7 \cdot 31^{\circ} \\
94 \cdot 90 \pm 9 \cdot 21\end{array}$ & $\begin{array}{l}11.70 \pm 0.29 \\
14.17 \pm 0.44 \\
15.44 \pm 0.91 \\
13.73 \pm 0.27 * * * \\
13.38 \pm 0.20^{\mathrm{c}} \\
12.69 \pm 0.45\end{array}$ \\
\hline Experiment D & $\begin{array}{c}\text { HGG }+1.5 \% \text { gelatine } \\
0.1 \text { i.u. }+0.1 \mathrm{ml} \\
0.2 \text { i.u. }+0.1 \mathrm{ml} \\
0.4 \text { i.u. }+0.1 \mathrm{ml} \\
\text { HCG }+ \text { ACTH } \\
0.1 \text { i.u. }+2.5 \mu \mathrm{g} \\
0.2 \text { i.u. }+2.5 \mu \mathrm{g} \\
0.4 \text { i.u. }+2.5 \mu \mathrm{g}\end{array}$ & $\begin{array}{c}86 \cdot 03 \pm 9.56 \\
117.29 \pm 10.45 \\
150.24 \pm 11.09 \\
81.35 \pm 7.63 \\
119.95 \pm 8.27 \\
111.00 \pm 9.59 *\end{array}$ & $\begin{array}{l}11.69 \pm 0.73 \\
14.54 \pm 1.22 \\
18.22 \pm 0.78 \\
12.55 \pm 0.39 \\
20.73 \pm 0.47 \\
14.84 \pm 0.55 * *\end{array}$ \\
\hline Experiment E & $\begin{array}{c}\text { HCG }+1.5 \% \text { gelatine } \\
0.05 \text { i.u. }+0.1 \mathrm{ml} \\
0.10 \text { i.u. }+0.1 \mathrm{ml} \\
0.20 \text { i.u. }+0.1 \mathrm{ml} \\
0.40 \text { i.u. }+0.1 \mathrm{ml} \\
\text { HCG }+ \text { ACTH } \\
0.05 \text { i.u. }+5.0 \mu \mathrm{g} \\
0.10 \text { i.u. }+5.0 \mu \mathrm{g} \\
0.20 \text { i.u. }+5.0 \mu \mathrm{g} \\
0.40 \text { i.u. }+5.0 \mu \mathrm{g}\end{array}$ & $\left.\begin{array}{r}25 \cdot 95 \pm 1 \cdot 24 \\
45 \cdot 95 \pm 3 \cdot 58 \\
89 \cdot 45 \pm 7 \cdot 88 \\
122 \cdot 26 \pm 9 \cdot 96\end{array}\right\}$ & $\left.\begin{array}{r}4.96 \pm 0.23 \\
8.00 \pm 0.51 \\
12.57 \pm 0.51 \\
19.44 \pm 1.03\end{array}\right\}$ \\
\hline
\end{tabular}

Values expressed as Means \pm S.E.M. There were twenty mice in each group.

Significance of differences between the gelatine and ACTH treatments: Student's $t$ test: * $P<0.05 ; * * P<0.01 ; * * * P<0.001$.

Comparison of regression coefficients: ${ }^{*} P<0.005$; $^{b} P<0.001$. 
housed in a room maintained at $23 \pm 1^{\circ} \mathrm{C}$, and were exposed to a controlled light cycle of $13 \mathrm{hr}$ light/ $11 \mathrm{hr}$ dark.

In all experiments, the mice were injected daily for 3 days and were killed on the 4th day. The dry and wet weights of the uterus were then determined. The following preparations were used: HCG (Choriogonin: Richter); $1.5 \%$ gelatine; $\beta 1-24$ ACTH (Synacthen retard: Ciba); oestradiol-17 $\beta$ (Sigma); dexamethasone (Oradexon: Organon). These substances were administered

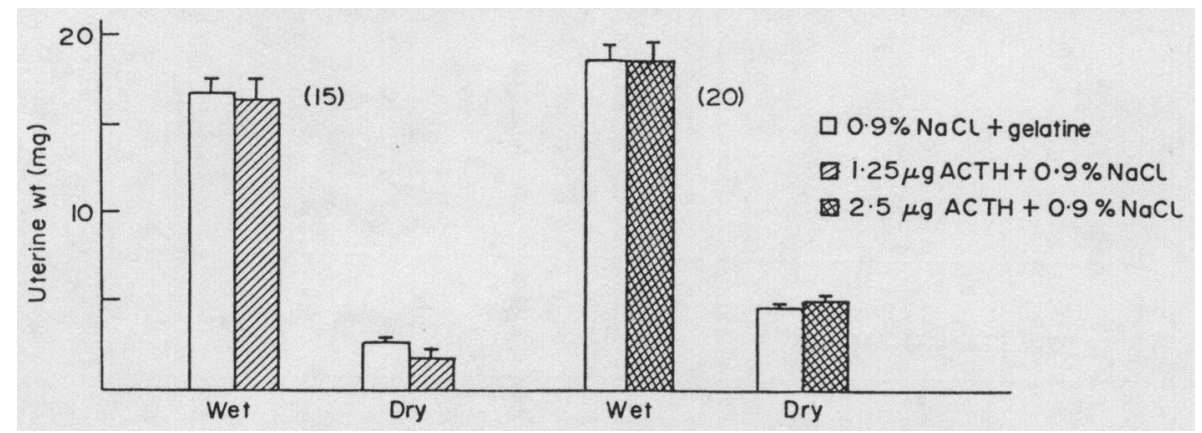

TEXT-FIG. 1. The effect of ACTH on uterine weight of mice. Vertical bars represent the S.E.M. Figures in parentheses are the numbers of animals.

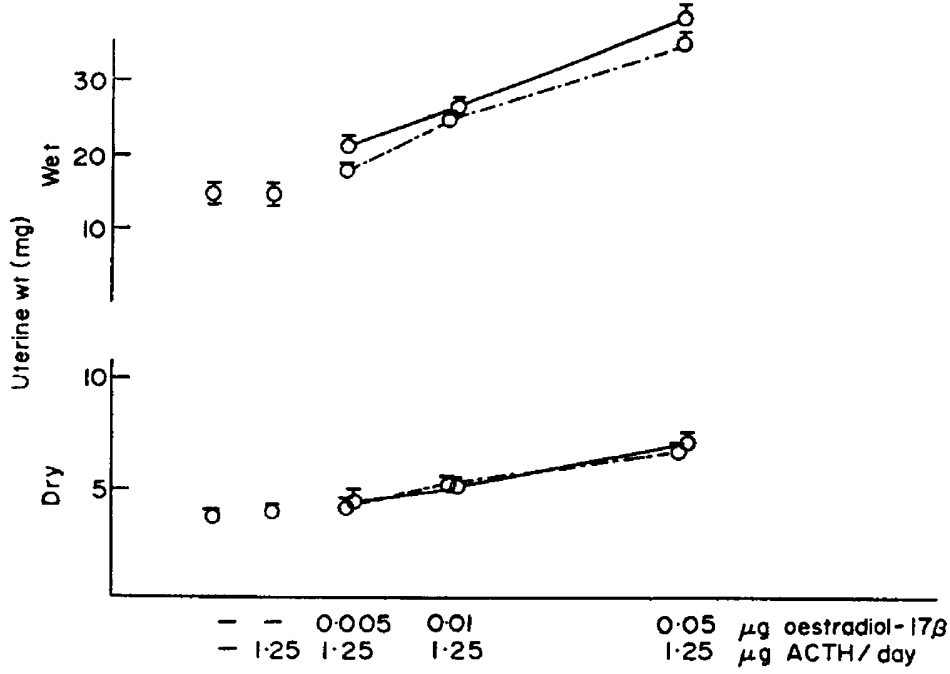

TEXT-FIG. 2. The effect of ACTH on the weight response of the uterus of mice $(N=12$ in each group) to increasing doses of oestradiol-17 $\beta$. Vertical bars represent the S.E.M. - , Oestradiol-17 $\beta+$ ACTH ; - ..... oestradiol-17 $\beta+$ gelatine.

intramuscularly $(0.1 \mathrm{ml}$ daily), simultaneously, but at different sites. Of the doses of HCG and oestradiol-17 $\beta$, half of each was given on the lst day of treatment, and a quarter of each on the 2nd and 3rd days. Dexamethasone and ACTH were administered in equal doses. Further details of the various experimental treatments are shown in Text-figs 1 to 4 and Table 1 .

Student's $t$ test or a comparison of regression coefficients was used for statistical analysis. 


\section{RESULTS}

The ACTH alone in doses of $1.25 \mu \mathrm{g}$ and $2.5 \mu \mathrm{g} /$ day had no effect on uterine weight (Text-fig. 1). In Exp. 2, the simultaneous administration of $1.25 \mu \mathrm{g}$ ACTH/day with oestradiol was shown not to influence the uterotrophic effect of increasing doses of the latter (Text-fig. 2). By contrast, ACTH (1.25 $\mu \mathrm{g} /$ day) increased the sensitivity of the uterus to sub-maximal doses of HCG (0.05 to

A

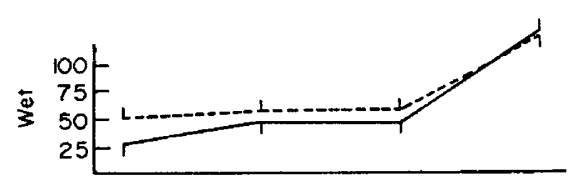

ㄴํํ

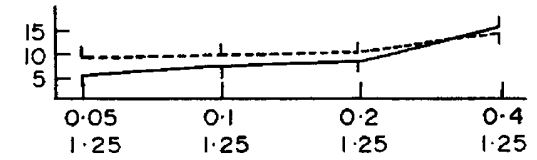

c
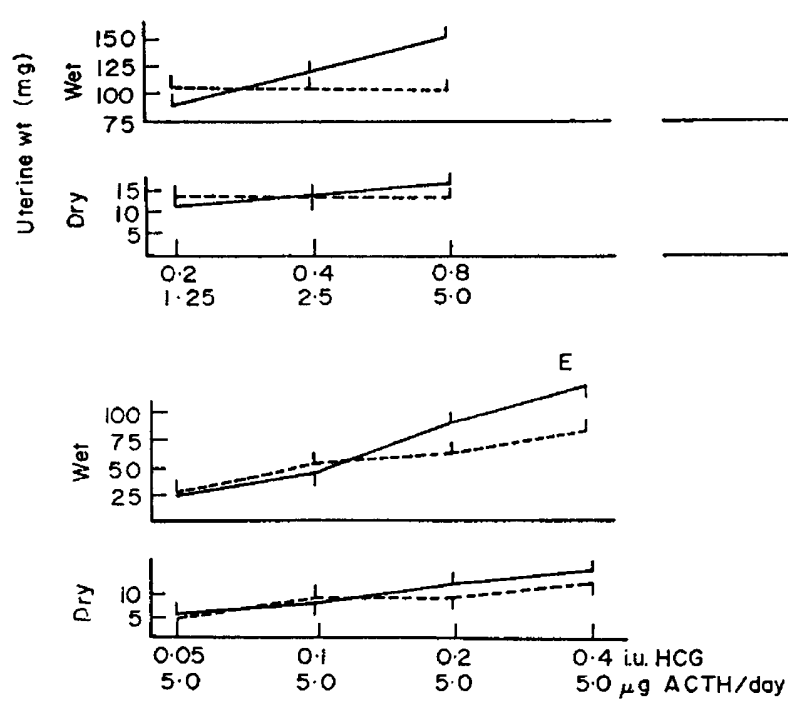

TEXT-FTG. 3. Dose-response curves for the uterine weights of mice treated with HCG and gelatine (-) or HCG and increasing doses of AGTH (--) in Exps A, B, C, D, and E, respectively (see Table 1). Vertical bars represent the S.E.M.
B
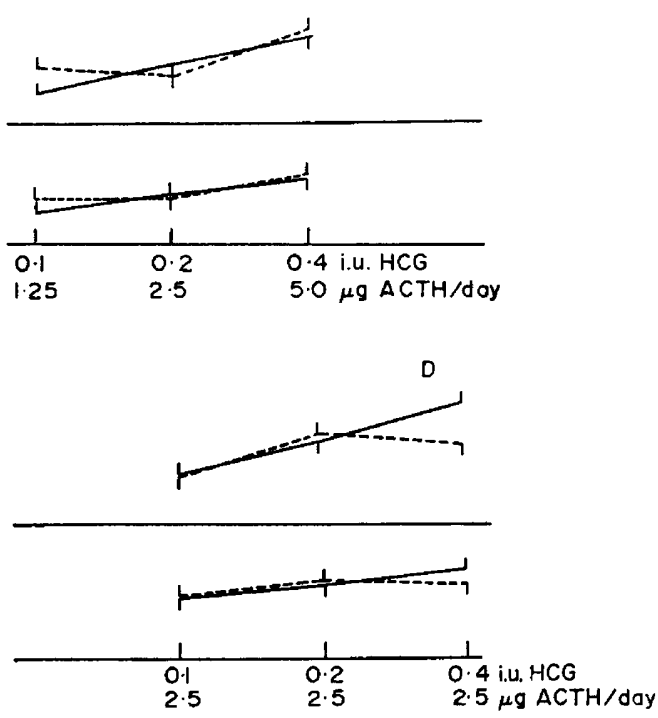

0.2 i.u., see Text-figs $3 \mathrm{~A}, \mathrm{~B}$ and C). Increased amounts of ACTH (2.5 to 5.0 $\mu \mathrm{g} /$ day) apparently inhibited the effect of high doses of HCG (0.2 to $0.8 \mathrm{i}$.u.) on uterine weight (Text-figs $3 \mathrm{C}, \mathrm{D}$ and E). Dexamethasone had no effect on the response of the uterus to HCG except when given in relatively high doses (10 $\mu \mathrm{g} /$ day, see Text-fig. 4). 


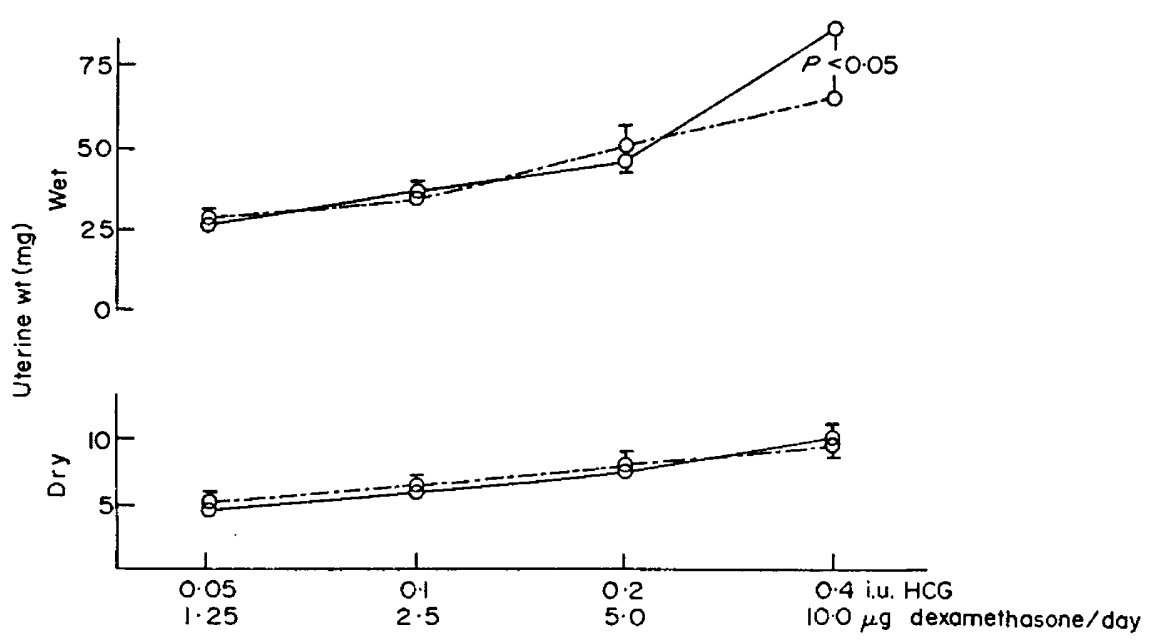

TexT- FIG.4. Uterine weight response to HGG in twenty mice per group treated with dexamethasone. Vertical bars represent the S.E.M. - , HCG $+0.9 \% \mathrm{NaCl}$; - HCG + dexamethasone.

\section{DISGUSSION}

The results of this study indicate that small amounts of ACTH increase the effect of low doses of HCG on the mouse uterus. Dexamethasone produces no such effect, and ACTH by itself is ineffective. Stimulatory doses of ACTH do not influence the effect of oestradiol-17 $\beta$ on the weight of the mouse uterus. Telegdy \& Huszár (1962) and Yogo (1969) have shown that HCG possesses LH and FSH activities and is known to exert its effect independently of endogenous gonadotrophic hormones (Stolzenberg \& Wilbur, 1970; Betteridge, 1971). In the dog, ACTH elicits a considerable rise in the secretion of dehydroepiandrosterone (DHEA) by the adrenal gland; HCG is ineffective (Egashira, 1971). According to Hipkin $(1970,1971)$, ACTH increases the weight response of the uterus to HCG by stimulating the adrenal cortex to produce more DHEA which in the ovary is turned into oestrogen. In women, ACTH increases oestrogen excretion after ovariectomy, ceases to do so following adrenalectomy, but again increases it after DHEA administration (Barlow, 1964). The DHEA itself possesses oestrogen-like activity (Sfikakis, Diamanti \& Varonos, 1972) and can change into oestrogen even in the absence of the ovary (Adams \& Brown, 1971). Baird, Uno \& Melby (1969) showed that ACTH augments the rate of oestrone secretion into human adrenal venous blood.

These data seem to justify the hypothesis that ACTH by itself can increase uterine weight but our own experiments failed to verify it. The ovarian blood flow in adrenalectomized dogs has been shown to be augmented by ACTH (Stark et al., 1967; Stark \& Varga, 1968). In the animals pretreated with HCG, ACTH stimulated ovarian oestrogen secretion both in the intact and adrenalectomized dogs (Varga et al., 1974). Without HCG treatment, this was not demonstrable in the anoestrous phase (Horváth, Stark \& Varga, 1969). It may be supposed that ACTH is able to increase the secretion of oestrogen by the mouse ovary following stimulation with HCG, though it exerts no effect on 
the ovarian blood flow in control (Varga \& Bukulya, 1974) or in HCG-treated animals (Varga, 1972). In control and HGG-treated mice (Hipkin, 1970) and rats (Hipkin, 1971), ACTH was found to stimulate the uterine weight. We have observed this effect in HCG-treated mice only after low doses of ACTH; high doses inhibited the uterine weight response to HCG. The corticosteroids may play a rôle in the inhibition caused by high doses of ACTH (Bitman \& Cecil, 1967). The decrease in uterine wet weight after dexamethasone, found in the present experiments, could also be attributed to an inhibitory effect of corticosteroids. In rats, high doses of AGTH inhibit ovulation induced by PMSG by increasing corticosteroid secretion; low doses are either ineffective or stimulate ovulation (Hagino et al., 1969).

In the rat, an elevated corticosterone level during the pro-oestrous phase indicates increased release of ACTH (Raps, Barthe \& Desaulles, 1971). At the same time, the adrenal cortex produces much progesterone, to which a prominent rôle is assigned in initiating ovulation (Feder et al., 1971; Nequin \& Schwartz, 1971). Observations on dogs (Varga et al., 1974) and the present experiments on mice suggest that in this 'critical period' of the cycle, ACTH acts directly on the ovary. Whether the effect of ACTH, as measured by different biological tests, is to be regarded, from the point of view of reproduction, as having a positive or a negative effect seems to depend not only on the amount of ACTH, but equally on the actual phase of the cycle.

\section{ACKNOWLEDGMENTS}

We wish to thank Miss E. Váczy and Mr J. Horváth for their valuable technical assistance.

\section{REFERENCES}

ADAMs, J. B. \& BROWN J. B. (1971) Increase in urinary excretion of oestrogen on administration of dehydroepiandrosterone sulphate to an adrenalectomized, oophorectomized patient with breast cancer. Steroidologia, 2, 1-6.

Baird, D. T., Uno, A. \& Melby, J. C. (1969) Adrenal secretion of androgens and oestrogens. $\mathcal{F}$. Endocr. 45, 135-136.

BarLow, J. J. (1964) Adrenocortical influences on oestrogen metabolism in normal females. $\mathrm{f}$. clin. Endocr. Metab. 24, 586-696.

Betteridge, K. J. (1971) Stimulation of rabbit ovaries by human chorionic gonadotrophin in the absence of endogenous gonadotrophins. F. Endocr. 51, 499-504.

Bitman, J. \& Gecil, H. C. (1967) Differential inhibition by cortisol of estrogen-stimulated uterine response. Endocrinology, 80, 423-429.

Egashrra, K. (1971) Some aspects of androgen secretion by the canine adrenal. Tohoku f. exp. Med. $105,35-43$.

Feder, H. H., Brown-Grant, K. \& Corker, C. S. (1971) Pre-ovulatory progesterone, the adrenal cortex and the "critical period" for luteinizing hormone release in rats. F. Endocr. 50, 29-39.

FEDER, H. H. \& RUF, K. B. (1969) Stimulation of progesterone release and estrous behavior by ACTH in ovariectomized rodents. Endocrinology, 84, 171-174.

Hagino, N., Watanabe, M. \& Goldzieher, J. W. (1969) Inhibition by adrenocorticotrophin of gonadotrophin-induced ovulation in immature female rats. Endocrinology, 84, 308-314.

Hagino, N. \& Yamaora, S. (1971) Influence of adrenal hormone on ovulation in the rat. Anat. Rec. 169,331, Abstr.

Hipkin, L. J. (1970) The effect of alteration in adrenocortical function on mouse uterine weight response to human chorionic gonadotrophin. Acta endocr., Copenh. 64, 95-102.

Hipkin, L. J. (1971) The effect of corticotrophin on the rat uterine weight response to human chorionic gonadotrophin. Acta endocr., Copenh. 67, 463-469. 
Horváth, E., Stark, E. \& Varga, B. (1969) [Extraction and quantitative determination of oestrogens from ovarian venous blood.] Orvostud. Beszám. 20, 241-249. [In Hungarian.]

LiPTRAP, R. M. (1970) Effect of corticotrophin and corticosteroids on oestrus, ovulation and oestrogen excretion in the sow. F. Endocr. 47, 197-205.

Nequin, L. G. \& Schwartz, N. B. (1971) Adrenal participation in the timing of mating and LH release in the cyclic rat. Endocrinology, 88, 325-331.

Raps, D., Barthe, P. L. \& Desauldes, P. A. (1971) Plasma and adrenal corticosterone levels during the different phases of the sexual cycle in normal female rats. Experientia, 27, 339-340.

REsKo, J. A. (1969) Endocrine control of adrenal progesterone secretion in the ovariectomized rat. Science, $\mathcal{N} . Y .164,70-71$.

Sikakis, A. P., Diamanti, E. \& Varonos, D. D. (1972) Effect of metirapone on the oestrogen-like effect of dehydroepiandrosterone. F. Endocr. 54, 367-368.

Smith, E. R., Johnson, J., Weick, R. F., Levine, S. \& Davidson, J. M. (1971) Inhibition of the reproductive system in immature rats by intracerebral implantation of cortisol. Neuroendocrinology, 8 , 94-106.

STARK, E. \& VARGA, B. (1968) Effect of ACTH on target organ blood flow, with special reference to an extra-adrenal effect. Acta med. hung. 25, 367-381.

Stark, E., VARGA, B. \& Ács, Zs. (1967) An extra-adrenal effect of corticotrophin. F. Endocr. 37, 245252.

Stolzenserg, S. J. \& WiLbUR, R. D. (1970) Effect of human chorionic gonadotrophin on the uterus and ovaries of hypophysectomized rats. F. Endocr. 46, 177-183.

Teleady, G. \& Huszár, L. (1962) The effect of FSH and HCG on the dog's ovarian progesterone and 4-androsterone-3,17-dione secretion in vivo. Acta physiol. hung. 21, 339-345.

VARGA, B. (1972) [The effects of ACTH on adrenal and ovarian blood flow.] Dissertation, Hungarian Academy of Sciences. [In Hungarian.]

Varga, B. \& Buxulya, B. (1974) Effects of a single and prolonged ACTH treatment on adrenal, ovarian, uterine and renal blood flow in mice and golden hamsters. Endokrinologie, 63, 17-22.

VARGA, B., Horváth, E. \& Stark, E. (1974) Effects of ACTH and HCG on ovarian oestrogen and progesterone secretion in dogs pretreated with HCG. Acta physiol. hung. 44, 29-37.

Varga, B., Stark, E., CsÁki, L. \& Marton, J. (1969) Effect of ACTH on gonadal blood flow in the golden hamster and the rat. Gen. $\mathcal{E}$ compar. Endocr. 13, 468-473.

YoGo, I. (1969) Biological properties of human chorionic gonadotrophin. Endocr. jap. 16, 215-226. 